\title{
EL ENJUCIAMIENTO PENAL DE LAS PERSONAS CON PROBLEMAS DE SALUD MENTAL
}

\author{
Tomás Farto Piay*
}

SUMARIO: 1. Consideraciones previas. 2. Regulación legal: tratamiento procesal diverso. 3. Posición de la jurisprudencia. 4. Imposibilidad de celebración de juicio oral: afectación de garantías y derechos. 5. Reflexiones en torno a la situación actual y la necesidad de acudir a la vía civil. 6. Conclusiones. 7. Bibliografía.

Resumen: En el presente trabajo se analiza la problemática que suscita el enjuiciamiento penal de aquellas personas que se encuentran privadas de capacidad procesal debido a una situación de enfermedad o trastorno mental que les impide conocer y participar válidamente en el proceso, cuestión que cuenta con una muy deficitaria

Recibido: diciembre 2020. Aceptado: junio 2021

* Profesor de Derecho Procesal. ORCID ID: https://orcid.org/0000-00033596-1074

Departamento de Derecho Público. Facultad de Ciencias Jurídicas y del Trabajo. Universidad de Vigo. Campus Univ. Lagoas Marcosende, 36310, Vigo, España. Email: tfarto@uvigo.es 
regulación procesal que hace peligrar los derechos fundamentales del sujeto pasivo del proceso. Asimismo, existe una doctrina jurisprudencial que mantiene criterios contradictorios al respecto, pues mientras algunas sentencias del Tribunal Supremo validan el enjuiciamiento penal del sujeto pasivo, aun a los efectos de imposición de una medida de seguridad, otras sentencias abogan por el archivo del proceso y remiten al proceso civil para acordar las medidas que correspondan, al considerar que no es posible celebrar juicio oral frente a quien carece de capacidad procesal suficiente por enfermedad o trastorno mental, pues así se vulnerarían sus derechos y garantías constitucionales.

Palabras clave: incapacidad procesal, enfermedad o trastorno mental, derecho de defensa, proceso penal.

\begin{abstract}
The current work analyzes the criminal prosecution of people who are deprived of procedural capacity due to a situation of illness or mental disorder preventing them from knowing and concious participating in the proceedings, a deficient issue that endangers the procedural regulation and the fundamental rights of passive subject in the proceedings. Likewise, there is a jurisprudential doctrine that maintains contradictory criteria on this regard, while some veredicts of the Supreme Court validate the criminal prosecution of the passive subject, even for the purposes of imposing a security measure, other veredicts advocate for the filing of the proceeding and refers them to a civil proceeding to agree on the corresponding measures, considering that it is not possible to hold an trial hearing against someone who lacks sufficient procedural capacity due to illness or mental disorder, as this would violate their rights and constitutional guarantees.
\end{abstract}

Keywords: procedural incapacity, mental illness or disorder, right of defense, criminal proceedings.

\title{
1. Consideraciones previas
}

La cuestión que nos atañe versa sobre el tratamiento que ha de otorgarse a personas con problemas de salud mental que deben enfrentarse a un proceso penal en calidad de 
sujetos pasivos. En particular, la problemática del enjuiciamiento de las personas que padecen una enfermedad o trastorno mental que les priva de la capacidad para comprender mínimamente el alcance, naturaleza y consecuencias que derivan del proceso ${ }^{1}$, así como de intervenir y llevar a cabo actuaciones básicas relacionadas con su defensa y su autodefensa; esto es, si como sujetos pasivos que carecen de capacidad procesal pueden o no ser sometidos a un juicio penal ${ }^{2}$.

La capacidad procesal la ostentan las personas que tienen la aptitud necesaria para participar de modo consciente en el juicio, comprender la acusación formulada contra ellas y ejercer el derecho de defensa. En caso contrario, de quedar acreditada ab initio la enfermedad mental, y dado que no se puede imponer una medida de seguridad si no es en la sentencia dictada tras el oportuno juicio contradictorio conforme a las exigencias del $\mathrm{CP}$, el problema estriba en si procede la apertura y celebración del juicio oral ${ }^{3}$.

1 MORENO CATENA ["Enfermedad mental y capacidad en el proceso penal”, en FLORES PRADA, I. (Dir.), SÁNCHEZ RUBIO, A. (Coord.), Trastornos mentales y justicia penal: Garantías del sujeto pasivo con trastorno mental en el proceso penal, Thomson Reuters Aranzadi, Cizur Menor (Navarra), 2017, pág. 79] se refiere a ello como "ese umbral mínimo de comprensión del sentido del procedimiento, de los motivos por los que se le hace comparecer ante un tribunal y de las consecuencias de la sentencia condenatoria que solicita la acusación".

2 Sobre la capacidad procesal en el proceso penal, vid. DE LA ROSA CORTINA, J.M., "Capacidad y proceso penal", Revista Aranzadi de Derecho y Proceso Penal, núm. 43, 2016, pág. 23-77; FLORES PRADA, I., "Problemas del enjuiciamiento de delitos violentos cometidos por inimputables", Revista Aranzadi de Derecho y Proceso penal, núm. 22, 2009, págs. 1-27; MORENO CATENA, V., "Enfermedad mental...", op. cit., págs. $69-88$.

3 MORENO CATENA, V., "La parte acusada", en MORENO CATENA, V., CORTÉS DOMÍNGUEZ, V., Derecho Procesal penal, 9a edición, Tirant lo Blanch, Valencia, 2019, pág. 120. En idéntico sentido, GOMEZ DE LIAÑO DIEGO, R., "Exigencias del derecho de defensa de los enfermos mentales investigados/acusados en un proceso penal", en FLORES PRADA, I. (Dir.), SÁNCHEZ RUBIO, A. (Coord.), Trastornos mentales y justicia penal: Garantías del sujeto pasivo con trastorno 
La problemática que se suscita es si la apertura y celebración del juicio colisiona con el derecho de defensa cuando se celebra en los casos en que el investigado se encuentra privado de capacidad para actuar de manera mínimamente válida o eficaz en el mismo a causa de la enfermedad mental que padece, absoluta y de carácter permanente ${ }^{4}$. A este respecto, el TS ha tenido la oportunidad de pronunciarse sobre estas situaciones y ha acordado la nulidad del juicio oral y sentencia subsiguiente ${ }^{5}$.

Por ello, la cuestión principal objeto de estas páginas estriba en determinar si, constatada la incapacidad del investigado para ser sometido a enjuiciamiento, o lo que es lo mismo su ausencia de capacidad procesal ${ }^{6}$, puede ser sometido a juicio oral, aun cuando lo fuese con el único objeto de acordar la imposición de una medida de seguridad en sentencia.

A estos efectos deviene imprescindible determinar la gravedad e intensidad de la dolencia o enfermedad psíquica en orden a la concreta repercusión en el enjuiciamiento en el proceso penal, desde el plano de las garantías y derechos fundamentales, lo que exige interpretar la normativa procesal bajo una óptica tanto constitucional como internacional y europea. En particular, en relación a esta última, cabe

mental en el proceso penal, Thomson Reuters Aranzadi, Cizur Menor (Navarra), 2017, pág. 267; MORENO CATENA, V., "Enfermedad mental...", op. cit., págs. 77-78.

4 GOMEZ DE LIAÑO DIEGO, R., "Exigencias del derecho de defensa de los enfermos mentales investigados en un proceso penal", en FLORES PRADA, I. (Dir.), Derechos y garantías del investigado con trastorno mental en el sistema de justicia penal, pág. 76 (http://www.trastornosmentalesyjusticiapenal.com/wp-content/uploads/Informe $\% 20$ inicial $\% 20 I \% 2 b D$.pdf, última consulta: 17/10/2018).

5 Vid. la STS 669/2006, de 14 junio (RJ 2006/4759).

6 Como advierte MORENO CATENA ("Enfermedad mental...", op. cit., págs. 70-71), las categorías procesales de los arts. 6 y 7 LEC no se pueden reproducir ni aplicar al proceso penal porque lo que se dilucida en el proceso penal es el ejercicio del ius puniendi, para lo cual se requiere la declaración de responsabilidad personal de quien ha sido acusado. 
destacar la Directiva (UE) 2016/343, de 9 de marzo, por la que se refuerzan en el proceso penal determinados aspectos de la presunción de inocencia y del derecho a estar presente en el juicio ${ }^{7}$.

Al respecto cumple realizar, con carácter previo, unas precisiones de orden terminológico o conceptual toda vez que esa enfermedad o trastorno mental es susceptible de hacer entrar en juego dos conceptos diferenciados, la capacidad procesal y la imputabilidad ${ }^{8}$. Así, la primera atañe a la capacidad o aptitud de actuar de forma válida en el proceso, permitiendo su concurrencia que la relación jurídico-procesal se constituya de manera validad o correcta; de otro lado, la imputabilidad viene referida al concepto de culpabilidad del sujeto, concebido como presupuesto de la penalidad exigido para la imposición de una pena por delito, dado que su concurrencia se hace precisa para que el comportamiento del autor sea antijurídico, antijuridicidad de la acción que, para erigirse en delictiva, además de punible requiere la imputabilidad del autor concebida como capacidad de comprender y conocer el carácter antijurídico de sus actos, y de ser capaz de obrar en consecuencia, pues en caso contrario quedaría excluida su responsabilidad penal. Ambos conceptos, capacidad procesal e imputabilidad, difieren, por tanto, en su naturaleza y esencia y aunque pueden presentarse simultáneamente en un mismo sujeto pasivo ello no tiene por qué ser necesariamente así, pues cada uno de ellos despliega sus

7 Directiva (UE) 2016/343, de 9 de marzo, por la que se refuerzan en el proceso penal determinados aspectos de la presunción de inocencia y del derecho a estar presente en el juicio (DOUE L núm. 65, de 11 de marzo de 2016).

8 Sobre la delimitación de los conceptos de imputabilidad y capacidad procesal, vid. SÁNCHEZ RUBIO, A., "Las garantías de defensa en el enjuiciamiento del enfermo mental”, en ÁLVAREZ ALARCÓN, A., GARCÍA MOLINA, P. (Dirs.), CONDE FUENTES, J., ARRABAL PLATERO, P. (Coords.), Tendencias actuales del Derecho Procesal, Comares, 2019, págs. 92-94. 
propios efectos y consecuencias en los momentos y ámbitos correspondientes.

Ha de matizarse que no se trata del análisis de la imputabilidad o inimputabilidad del sujeto, como capacidad de culpabilidad, que guardaría relación con cuál era su situación mental en el momento de la comisión de los hechos y el grado de afectación del mismo a dicha fecha como posible causa de exención de responsabilidad penal, sino de la incapacidad procesal entendida como ausencia de aptitud para intervenir consciente y eficazmente en un juicio penal en relación a su propia defensa, como elemento fundamental del derecho a un proceso justo en la amplitud de términos y actuaciones ya señalados? ${ }^{9}$ En palabras de FLORES PRADA, "capacidad procesal e inimputabilidad pueden venir condicionadas por el mismo o diferentes trastornos mentales, dándose además la posibilidad de que el trastorno mental que elimine la imputabilidad no restrinja la capacidad procesal y viceversa"10; por tanto, habrá que distinguir entre las mismas, como situaciones intelectuales diferentes ${ }^{11}$.

9 GARCÍA SAN MARTÍN, J., "Incapacidad de obrar "versus inimputabilidad: dos realidades no necesariamente convergentes", en FLORES PRADA, I. (Dir.), SÁNCHEZ RUBIO, A. (Coord.), Trastornos mentales y justicia penal: Garantías del sujeto pasivo con trastorno mental en el proceso penal, Thomson Reuters Aranzadi, Cizur Menor (Navarra), 2017, págs. 173 y 174; HERNÁNDEZ GALILEA, J.M., "El control de la capacidad procesal del investigado en el proceso penal", en FLORES PRADA, I. (Dir.); SÁNCHEZ RUBIO, A. (Coord.), Trastornos mentales y justicia penal: Garantías del sujeto pasivo con trastorno mental en el proceso penal, Thomson Reuters Aranzadi, Cizur Menor (Navarra), 2017, pág. 192; VARELA CASTEJÓN, X., "A persoa incapaz ante o proceso penal”, Revista Xurídica Galega, núm. 69, 2010, pág. 32.

10 FLORES PRADA, I., "Problemas del enjuiciamiento...", op. cit., pág. 138.

11 QUINTERO OLIVARES, G., "Culpabilidad, imputabilidad y capacidad procesal en el derecho en el derecho penal y en el enjuiciamiento de personas con trastorno mental", en FLORES PRADA, I. (Dir.), SÁNCHEZ RUBIO, A. (Coord.), Trastornos mentales y justicia penal: Garantías del sujeto pasivo con trastorno mental en el proceso penal, 
También procede aclarar que la incapacidad procesal referida no es un concepto equivalente al de persona con incapacidad declarada judicialmente, pues ésta no supone, siempre y en todo caso, que la persona carezca necesariamente de capacidad procesal para intervenir de modo consciente y eficaz en el proceso penal ${ }^{12}$.

Asimismo, es conveniente diferenciar entre la defensa técnica del sujeto pasivo del proceso penal, necesariamente ejercitada por letrado, del concepto y derecho fundamental de autodefensa, pues una cosa es el derecho fundamental a la asistencia letrada y otra el derecho de autodefensa a ejercitar por el propio sujeto ${ }^{13}$, con el elenco de intervenciones y derechos que lo integran y en que puede manifestarse. Ello sin perjuicio de que el trastorno mental pueda afectar a ambos, claramente al derecho de autodefensa si la persona no comprende ni lo puede desarrollar o llevar a efecto por dicha causa, pero también el derecho a defensa técnica que exige una comunicación normalizada y coordinación eficaz entre letrado y defendido, lo que la enfermedad mental puede obstaculizar o imposibilitar.

\section{Regulación legal: tratamiento procesal diverso}

Ciertamente, es necesario advertir que la regulación vigente relativa a la cuestión que nos ocupa es extremadamente

Thomson Reuters Aranzadi, Cizur Menor (Navarra), 2017, pág. 31. En el mismo, sentido, VARELA CASTEJÓN, X., "A persoa incapaz...”, op. cit., pág. 32 .

12 VARELA CASTEJÓN, X., "A persoa incapaz...”, op. cit., pág. 31. En relación a su intervención en el proceso, vid. ORTEGA LORENTE, J.M., "44. ¿El acusado psíquicamente discapacitado, puede intervenir en juicio con la mera asistencia de letrado, o debe estar asistido, también, por su tutor, guardador de hecho o defensor judicial?", en BACH FABREGÓ, R., (Dir.), 84 cuestiones sobre la dirección y publicidad del juicio oral, CGPJ, Madrid, 2011, págs. 164-168.

13 MORENO CATENA, V., "Enfermedad mental...” op. cit., pág. 79. 
deficiente ${ }^{14}$. Como se verá, las normas que la LECrim dedica al enjuiciamiento de sujetos que padecen un trastorno mental no son sólo anticuadas, descoordinadas y confusas, sino que además son, y es lo más grave, contrarias a la $\mathrm{CE}$ en cuanto imponen, sin alternativa, el enjuiciamiento de un sujeto que, por causa de un trastorno mental, carece de la mínima capacidad para entender el significado del proceso y para ejercer el derecho de defensa.

Expuesto lo anterior, en cuanto a la actual regulación relativa al investigado o acusado que presenta un trastorno psíquico o enfermedad mental, se encuentra en los arts. 381, 382 y 383 LECrim en sede de sumario, junto a la previsión contenida en el art. 782.1 LECrim, relativa al procedimiento abreviado $^{15}$.

Pues bien, la LECrim distingue entre dos situaciones distintas: de un lado, el art. 381 LECrim se refiere a los supuestos en que la incapacidad concurría en el momento de la comisión del hecho delictivo y persistía durante el proceso y, de otro, el art. 383 LECrim referido a los supuestos de incapacidad sobrevenida a la comisión del hecho delictivo ${ }^{16}$.

14 FLORES PRADA, I., "Derechos fundamentales y garantías del investigado con trastorno mental en el moderno sistema de justicia penal", en FLORES PRADA, I. (Dir.), Derechos y garantías del investigado con trastorno mental en el sistema de justicia penal, pág. 14 (http://www.trastornosmentalesyjusticiapenal.com/wp-content/uploads/Informe $\% 20$ inicial $\% 20 I \% 2 b D$.pdf, última consulta: 17/10/2018).

15 Sobre esta regulación, vid. FLORES PRADA, I., "Problemas del enjuiciamiento...", op. cit., págs. 4-11; SÁNCHEZ RUBIO, A., "La celebración de juicio oral contra enfermos mentales con incapacidad procesal plena”, en FLORES PRADA, I. (Dir.), Derechos y garantías del investigado con trastorno mental en el sistema de justicia penal, págs. 108-109 (http://www.trastornosmentalesyjusticiapenal.com/wpcontent/uploads/Informe $\% 20$ inicial $\% 20 \mathrm{I} \% 2 \mathrm{bD}$.pdf, última consulta: 17/10/2018).

16 Sobre esta distinción, vid. FLORES PRADA, I., "Garantías constitucionales en el enjuiciamiento de acusados con falta de capacidad procesal por trastornos mental grave", en FLORES PRADA, I. (Dir.), 
En el primer caso, a los efectos de acreditar la enfermedad mental, el juez instructor acordará que sea emitido informe por el médico forense (art. 381 LECrim) además de recabar información acerca de la enajenación mental del procesado (art. 382 LECrim); todo ello con el objeto de garantizar el derecho de defensa del investigado en los casos en que se aprecien motivos para sospechar de la existencia de posibles limitaciones de la capacidad procesal del mismo. Se trata de conocer la capacidad del acusado para comprender el desarrollo del juicio, en particular, para entender las preguntas que se le dirijan y las consecuencias de una posible oferta de conformidad, con indicación, si fuere posible, de la duración previsible de la limitación o su irreversibilidad, en su caso $^{17}$. De quedar acreditada tal enfermedad mental que implique su falta de capacidad procesal, se habrá de acordar el sobreseimiento libre conforme al art. 637.3 LECrim.

De otro lado, el art. 782.1 LECrim dispone que si el MF y el acusador particular solicitaren el sobreseimiento de la causa por cualquiera de los motivos que prevén los arts. 637 y 641 LECrim, lo acordará el Juez, excepto en los supuestos de los números $1 .^{\circ}, 2 .^{\circ}, 3 .^{\circ}, 5 .^{\circ}$ y $6 .^{\circ}$ del art. $20 \mathrm{CP}$, en que devolverá las actuaciones a las acusaciones para calificación, continuando el juicio hasta sentencia, a los efectos de la imposición de medidas de seguridad y del enjuiciamiento de la acción civil, en los supuestos previstos en el CP.

SÁNCHEZ RUBIO, A. (Coord.), Trastornos mentales y justicia penal: Garantías del sujeto pasivo con trastorno mental en el proceso penal, Thomson Reuters Aranzadi, Cizur Menor (Navarra), 2017, págs. 376385; SÁNCHEZ RUBIO, A., "Las garantías de defensa...", op. cit., págs. 95-100.

17 POZA CISNEROS, M., “¿Qué solución debe adoptarse en el caso de que se advierte que el imputado carece de la capacidad para comprender el desarrollo del proceso, en especial cuando ello se debe a una limitación que ya existía en el momento de comisión del delito?", en HERNÁNDEZ GARCÍA, J. (Dir.), Manuales de formación continuada (ejemplar dedicado a 99 cuestiones básicas sobre la prueba en el proceso penal), CGPJ, Madrid, núm. 51, 2009, pág. 41. 
Atendido el tenor del art. 782.1 LECrim, se colige la necesidad de abrir juicio oral en los supuestos de concurrencia de causa de inimputabilidad por anomalía o alteración psíquica al momento de cometerse el delito por la referencia expresa al art. $20.1^{\circ} \mathrm{CP}$, quedando al margen del precepto los supuestos de "demencia", enfermedad o trastorno mental, cuando ésta sobrevenga tras la comisión del ilícito. La obligatoriedad de apertura de juicio oral que se prevé para el procedimiento abreviado se extiende para todos los procesos penales por aplicación del art. $101 \mathrm{CP}^{18}$.

En este orden de ideas, se ha puesto de manifiesto que la ausencia de una regulación que permita atender a las necesidades derivadas de actuar cautelarmente sobre un sujeto que padece una enfermedad mental, se ha invocado el art. 381 LECrim como fundamento para acordar la prisión provisional; si bien este precepto sólo señala que, si existen indicios de enfermedad mental, habrá de recabarse en todo caso un informe médico forense del procesado, sometiéndose a éste a observación a efectos de emitir ese informe ${ }^{19}$.

En el segundo supuesto, si se trata de demencia sobrevenida después de cometido el delito, el art. 383 LECrim dispone que, concluso que sea el sumario, se mandará archivar la causa por el tribunal competente hasta que el procesado recobre la salud, disponiéndose además respecto de éste lo que el CP prescribe para los que ejecutan el hecho en estado

18 FLORES PRADA, I., "Derechos fundamentales y garantías...", op. cit., pág. 16.

19 ARNÁIZ SERRANO, A., "Adecuación de las vigentes medidas cautelares a aplicar sobre investigados con trastorno mental", en FLORES PRADA, I. (Dir.), SÁNCHEZ RUBIO, A. (Coord.), Trastornos mentales y justicia penal: Garantías del sujeto pasivo con trastorno mental en el proceso penal, Thomson Reuters Aranzadi, Cizur Menor (Navarra), 2017, pág. 238-39. Sobre la indebida aplicación de la prisión provisional, vid. SANZ MORÁN, Á.J., "La situación procesal del inimputable”, en ARANGÜENA FANECO, C. (Coord.), Garantías procesales en los procesos penales en la Unión Europea, Lex Nova, Valladolid, 2007, págs. 327-344. 
de demencia ${ }^{20}$. La primera parte del precepto referida al archivo provisional del proceso por falta de capacidad resulta adecuada con la $\mathrm{CE}^{21}$; sin embargo, la segunda parte, relativa a que se pueda adoptar alguna de las medidas de seguridad del art. $101 \mathrm{CP}$ resulta incompatible con el marco constitucional vigente si no es tras el oportuno juicio contradictorio previo $^{22}$.

En relación a ello, hay que señalar que la regulación propuesta en el Anteproyecto de LECrim de 2020 sobre la falta de capacidad absoluta del encausado en el proceso penal tampoco resuelve satisfactoriamente la cuestión relativa a la protección de los derechos del sujeto pasivo del proceso penal que carece de capacidad procesal, pues las soluciones propuestas no difieren en exceso del régimen vigente. Así, se prevé que, cuando el juez o tribunal declare la existencia de una discapacidad que impida completamente a la persona encausada comprender el significado y las consecuencias del proceso seguido en su contra, se constituya una institución de apoyo que asuma su asistencia integral y el procedimiento

20 En la Memoria de la Fiscalía General del Estado relativa a 2018 se propone la modificación del art. 383 LECrim. Sobre las consultas elevadas a las Fiscalía General del Estado en la materia, vid. MUÑIZ ANTEQUERA, A.J.; "Derecho de defensa, juicio oral y acusado con incapacidad procesal por trastorno mental. Alternativas ail enjuiciamiento mental de incapaces", en FLORES PRADA, I. (Dir.), SÁNCHEZ RUBIO, A. (Coord.), Trastornos mentales y justicia penal: Garantías del sujeto pasivo con trastorno mental en el proceso penal, Thomson Reuters Aranzadi, Cizur Menor (Navarra), 2017, págs. 346-348.

21 DE LA ROSA CORTINA (“Capacidad y...”, op. cit., pág. 34) señala que "La resolución procedente en estos casos es la de archivo provisional, no de sobreseimiento provisional del artículo 641.1 LECrim, aunque los efectos en la práctica son los mismos. Este archivo en base al art. 383 LECrim lo será en todo caso sin perjuicio de su reapertura si el imputado recobra la razón”. En idéntico sentido, DE LA ROSA CORTINA, J.M., "Medidas cautelares personales en supuestos de graves anomalías psíquicas”, La Ley Penal, núm. 108, 2014, pág. 10.

22 FLORES PRADA, I., "Derechos fundamentales y garantías...", op. cit., pág. 18. 
de investigación continuará hasta su conclusión, durante el cual la persona encausada será defendida por el abogado designado por la institución de apoyo y, en defecto de designación, por abogado de oficio. Asimismo, se dispone que, concluida la investigación, cuando en atención al hecho punible se entienda que la continuación del procedimiento solo puede tener por objeto la imposición de una pena, se decretará el archivo de las actuaciones hasta que la persona investigada recobre la capacidad necesaria para ser sometida a juicio, de modo que si llegara a recobrar la capacidad se procederá a la reapertura del procedimiento.

De otro lado, el Anteproyecto de LECrim de 2020 prevé que cuando, con arreglo al $\mathrm{CP}$, resulte procedente la imposición de una medida de seguridad, se dictará decreto acordando la conclusión del procedimiento de investigación y la continuación del proceso, con el ejercicio exclusivo de la acción penal por el MF y a los solos efectos de imponer una medida de seguridad, estableciéndose unas especialidades procesales para el juicio oral, como la intervención de una institución de apoyo, que deberá asistir al acusado y comparecer a juicio, pudiendo exceptuarse la presencia de la persona acusada en el juicio oral en atención a su estado, si bien resulta preceptiva su representación por procurador y la defensa letrada, con una prohibición expresa de la conformidad, no obstante cuando no exista controversia sobre la autoría del hecho y el tribunal lo considere adecuado, el juicio oral podrá celebrarse exclusivamente a los efectos de determinar la peligrosidad del acusado y la medida de seguridad a imponer ${ }^{23}$.

23 Así, en el Anteproyecto de LECrim de 2020, ex arts. 79 y 80, se contienen unas previsiones específicas relativas a la falta de capacidad absoluta del encausado en el proceso penal. Es así que el art. 79.1 del Anteproyecto establece que "Si una discapacidad impide completamente que la persona encausada comprenda el significado y las consecuencias del proceso que se sigue en su contra, el juez o tribunal lo declarará así en la resolución que ponga término al incidente regulado en el artículo 72 de 
Sentado el marco normativo procesal, la cuestión que deviene imprescindible determinar es si resulta posible o necesaria la apertura del juicio oral a fin de imponer alguna medida de seguridad en la correspondiente sentencia pese a que conste acreditado, a medio de los informes médicos oportunos, que el investigado carece de capacidad para

esta ley", disponiendo seguidamente que "en este supuesto, la persona que integre la institución de apoyo asumirá la asistencia integral de la persona encausada y el procedimiento de investigación continuará hasta su conclusión. En todo caso, durante el procedimiento de investigación la persona encausada será defendida por el abogado designado por quien integre la institución de apoyo y en defecto de esta designación se nombrará abogado del turno oficio".

Por su parte, el art. 79.2.1 ${ }^{\circ}$ del Anteproyecto prevé que, una vez concluida la investigación, el Ministerio Fiscal "Cuando, en atención a las circunstancias y características del hecho punible, entienda que la continuación del procedimiento solo puede tener por objeto la imposición de una pena, decretará el archivo de las actuaciones hasta que la persona investigada recobre la capacidad necesaria para ser sometida a juicio", previéndose que "si una vez decretado el archivo la persona encausada llegara a recobrar la capacidad, se procederá a la reapertura del procedimiento". De otro lado, el art. 79.2.2 $2^{\circ}$ señala que el Ministerio Fiscal "Cuando, con arreglo a lo dispuesto en el Código Penal, resulte procedente la imposición de una medida de seguridad, dictará decreto acordando la conclusión del procedimiento de investigación y la continuación del proceso. En este supuesto, la acción penal será ejercida exclusivamente por el Ministerio Fiscal a los solos efectos de que se adopte la medida de seguridad que resulte adecuada. No obstante, si hubiera acusaciones particulares personadas, estas podrán continuar en el procedimiento en calidad de actores civiles".

En este orden de cosas, el art. 80 del Anteproyecto regula las especialidades procesales del juicio oral para la imposición de una medida de seguridad, de las que destaca la intervención de una "institución de apoyo" que deberá asistir al acusado y comparecer a juicio, pudiendo exceptuarse la presencia de la persona acusada en el juicio oral en atención a su estado, siendo preceptiva la representación por procurador y la defensa letrada, con expresa prohibición de la conformidad, si bien cuando no exista controversia sobre la autoría del hecho punible y el tribunal lo considere adecuado a la vista de las circunstancias, el juicio oral podrá celebrarse exclusivamente a los efectos de determinar, con las pruebas testificales y periciales pertinentes, la peligrosidad de la persona acusada y la medida de seguridad procedente. 
enfrentarse al correspondiente juicio al carecer de capacidad para entender lo que ello supone, cuestión que afectaría a su derecho a un juicio justo ${ }^{24}$.

\section{Posición de la jurisprudencia}

Las soluciones dadas por la jurisprudencia en respuesta a la cuestión planteada son, como se expondrá seguidamente, dispares ${ }^{25}$; en algunas ocasiones, ha abogado por la necesidad de abrir juicio oral a fin de que se tramite el correspondiente proceso penal en cuya resolución final se acuerde la medida de seguridad que ha imponerse, toda vez

24 La acreditación de la ausencia de capacidad, o incapacidad procesal, del sujeto pasivo del proceso penal habrá de realizarse a medio de la correspondiente prueba pericial médica, esto es, a través de dictámenes o informes periciales en los que se somete a examen y análisis el estado o la situación mental del investigado o encausado, labor que, con carácter general, vendrá desarrollada por médicos forenses, o psiquiatras. Dicha prueba, que deberá determinar las circunstancias concurrentes sobre la enfermedad o trastorno mental, ha de servir al órgano judicial para, previa su valoración de conformidad a la regla de la sana crítica, alcanzar una conclusión respecto de la capacidad jurídico-procesal del sujeto pasivo.

25 Vid. FLORES PRADA, I., Peligrosidad social predelictual y trastorno mental, Thomson Reuters Aranzadi, Cizur Menor (Navarra), 2017, págs. 158-165; FLORES PRADA, I., "Garantías constitucionales...", op. cit., págs. 395-399 y 406-412; GALDEANO SANTAMARÍA, A., "El maltratador de violencia de género inimputable versus esposa-cuidadora víctima de violencia de género”, Diario La Ley, núm. 7967, Sección Doctrina, 2012, págs. 4-9; GRIMA LIZANDRA, V., "El derecho de defensa del imputado con graves anomalías psíquicas", en Revista Jurídica de la Comunidad Valencia: jurisprudencia seleccionada de la Comunidad Valenciana, núm. 34, 2010, págs. 74-84; LLEDÓ GONZÁLEZ, C.L., "Enfermedad mental y jurisprudencia", Cuadernos Digitales de Formación, CGPJ, núm. 55, 2016, págs. 29-44; POZA CISNEROS, M., “QQué solución debe adoptarse...”, op. cit., págs. 33-35; SÁNCHEZ RUBIO, A., "La celebración de juicio oral...", op. cit., págs. 109-113; VARELA CASTEJÓN, X., "A persoa incapaz...,", op. cit., págs. 34-40; SÁNCHEZ RUBIO, A., "Las garantías de defensa...", op. cit., págs. 100-103. 
que no es posible acordar una medida de seguridad sin una sentencia previa según determina nuestro CP (arts. 95 y 101 en relación al art. 3.1) así como la CE. Por el contrario, en otras resoluciones, se ha considerado que el proceso penal debía archivarse y acordarse las medidas necesarias a través del correspondiente proceso civil al entender que no es posible celebrar juicio oral frente a la persona física que carece de capacidad procesal suficiente por esa enfermedad o trastorno mental, pues ello vulneraría sus derechos y garantías constitucionales.

Esto es, se ha abogado por distintas soluciones que tienen fundamentos diversos y que explicitan claramente la necesidad de una regulación que sea acorde con la $\mathrm{CE}$ y con los Convenios internacionales que sobre la materia ha suscrito nuestro país, así como con la normativa europea ${ }^{26}$.

Tal disyuntiva de planteamientos y soluciones de nuestros tribunales, en sintonía con la dualidad de posiciones, se plasma en la STS de 21 de diciembre de 2017, que afirma que "El problema suscitado sugiere, pues, dos opciones interpretativas. La primera, el dictado por el Juez instructor de una resolución de archivo de la causa penal, con la consiguiente remisión de los antecedentes psiquiátricos del acusado al Ministerio Fiscal para el ejercicio de la acción civil de incapacitación, con la eventual adopción de una medida jurisdiccional tuitiva de ingreso en un centro psiquiátrico.

26 Entre otros, cabe reseñar el CEDH, PIDCP, DUDH o CDFUE sobre derecho a un juicio justo, así como la Convención sobre los Derechos de las Personas con Discapacidad firmada en Nueva York el 13 de diciembre de 2006 y ratificada por España el 23 de noviembre de 2007. En cuanto a la normativa de la Unión Europea, es preciso citar la Directiva 2016/343/UE, de 9 de marzo de 2016, por la que se refuerzan en el proceso penal determinados aspectos de la presunción de inocencia y del derecho a estar presente en el juicio o la Directiva 2012/13/UE del Parlamento Europeo y del Consejo de 22 de mayo de 2012 relativa al derecho a la información en los procesos penales. 
La segunda, la conclusión del sumario conforme a la regla general y la celebración de un juicio oral que tendría como desenlace una sentencia en la que se impusiera, después de un debate contradictorio, la medida de seguridad de internamiento prevista por el $\mathrm{CP}{ }^{27}$. Cabe reseñar que, aun cuando la meritada sentencia, recoge la existencia de las dos corrientes jurisprudenciales señaladas, no se posiciona en favor de ninguna de ellas en concreto toda vez que el supuesto debatido no lo exigía para la decisión de la cuestión planteada ante el Alto Tribunal.

Pues bien, entrando en el análisis de los pronunciamientos jurisprudenciales sobre el tema, ha de partirse necesariamente de la STS de 2 de abril de 1993 que, con fundamento en las garantías del proceso y los derechos fundamentales de las personas sometidas a enjuiciamiento, particularmente el derecho a un juicio justo, el necesario equilibrio e igualdad de armas entre partes, el derecho de defensa y el derecho de autodefensa, concluye que la ausencia en el acusado de las facultades mentales necesarias para afrontar un juicio penal supone que éste no ha disfrutado del derecho a un juicio justo y con todas las garantías, ocasionando efectiva indefensión vulneradora del art. 24.1 $\mathrm{CE}^{28}$.

27 STS 844/2017, de 21 de diciembre (RJ 2017/5791). Por su parte, el AAP de Pontevedra 9/2019, de 16 enero (JUR 2019/46667), pone de manifiesto las dos doctrinas jurisprudenciales, si bien concluye que, atendidos los informes forenses, no resulta indubitadamente adverado que la situación mental en que actualmente se encuentra la investigada resulte permanente e irreversible, de modo que no pudiera llegar a revertirse tal estado mental a otro estado que permitiese su sometimiento a juicio oral con pleno respeto de los derechos que le asisten y amparan, es decir, alcanzar o disponer de capacidad procesal para ser enjuiciada en el plenario.

28 Es así que la STS de 2 de abril de 1993 (RJ 1993/3072) se pronuncia en los siguientes términos "El equilibrio necesario entre las partes que interviene en el proceso penal exige de manera imperiosa el pleno ejercicio del derecho de defensa que se vertebra en diversas opciones. El derecho de asistencia letrada y el derecho a la autodefensa constituyen los pilares 
En consecuencia, el TS anula la sentencia condenatoria dictada por el órgano de instancia, reponiendo las actuaciones hasta el momento de comenzar las sesiones del juicio oral $^{29}$, señalando que resulta de aplicación lo dispuesto en el art. 383 LECrim respecto del procesado que cayese en estado de demencia después de cometido el delito, y disponiendo que, una vez desaparezcan las causas que han motivado la anulación y suspensión del juicio oral, deberá ser éste celebrado por un tribunal distinto del que ha conocido anteriormente.

No obstante, la dificultad de alcanzar una solución ante este tipo de situaciones llevó a la emisión de un voto particular que mantuvo una posición discrepante a la mayoritaria de la sala, al considerar que la interpretación del art. 383 LECrim que se mantiene vulnera claramente la CE al

básicos sobre los que se asienta un proceso con la debida adecuación a las exigencias constitucionales.

Las facilidades para dotar a una persona de la debida asistencia técnica de letrados aparecen recogidas en nuestro ordenamiento a través de varias disposiciones de la Ley de Enjuiciamiento Criminal y han sido debidamente satisfechas en este proceso. Pero el complemento ineludible de esta garantía viene constituido por la posibilidad efectiva de ejercitar con eficacia el derecho a la autodefensa siguiendo con la debida atención todas las vicisitudes del proceso y haciendo a su abogado y al Tribunal aquellas observaciones que fuesen pertinentes sobre el desarrollo de las pruebas o sobre cualquier otra incidencia o circunstancia que pueda surgir en el desarrollo del juicio.

No existió una verdadera igualdad de armas procesales. El recurrente no se encontraba con las facultades mentales necesarias para afrontar un juicio de gran trascendencia para sus intereses en cuanto que se solicitaba y se impuso la pena máxima prevista por nuestro ordenamiento penal, lo que hacía necesario que hubiese gozado de todos los medios necesarios para defenderse y especialmente, para afrontar su interrogatorio desde el principio del juicio y para poder ponerse de acuerdo eficazmente con su Abogado".

29 La SAP de Madrid 329/2016, de 30 de mayo (JUR 2016/161078) acuerda la nulidad del juicio celebrado, y la sentencia subsiguiente, a fin de que se proceda a acreditar si la demencia del acusado es permanente e irreversible, y en su caso resulte de aplicación el art. 383 LECrim. 
permitir la aplicación de las medidas de seguridad previstas en el CP para inimputables o incapaces de culpabilidad sin proceso previo; debiendo recordarse que las medidas de seguridad previstas en el texto penal constituyen consecuencias jurídicas del Derecho Penal que sólo se deben aplicar luego de que en un juicio con todas las garantías se haya demostrado que el acusado es el autor de una acción típica y antijurídica y que presenta la peligrosidad que justifica la medida ${ }^{30}$.

30 Se continúa señalando en el voto particular a la STS de 2 de abril de 1993 que "No existe ninguna razón para privar de estas garantías a una persona simplemente porque no se puede defender por sí misma. Por el contrario: Resulta totalmente infundado que la imposibilidad del acusado de autodefenderse determine sin más que las consecuencias jurídicas del delito previstas para tales casos se puedan aplicar sin juicio previo y sin las garantías que éste implica. De esta manera, en lugar de proteger al acusado que no se puede defender, se lo priva de toda posibilidad de ser juzgado ante un Tribunal imparcial y, consecuentemente, no se lo trata como una persona sino como un objeto carente de los derechos procesales fundamentales para la protección de una libertad que también está garantizada por el art. 17.1 de la Constitución Española a los enfermos mentales.

La necesidad del juicio, por otra parte, proviene del hecho que el art. 383 de la Ley de Enjuiciamiento Criminal en su expresión literal permite la aplicación de lo que dispone el Código Penal para los que ejecutan el hecho en estado de demencia. Es claro que lo dispuesto por el Código Penal es una medida de seguridad y que éstas no se pueden aplicar sin constatar previamente la comisión de un hecho típico y antijurídico. En el orden jurídico de España la existencia de este hecho típico y antijurídico depende de que se lo haya establecido en una Sentencia judicial que, como es obvio, sólo es válida como consecuencia de un juicio con todas las garantías, dado que no existe razón alguna que permita excluir que el enfermo mental sea absuelto. Privarle de esta posibilidad vulnera claramente su derecho a un juicio justo en el sentido del art. 6 del Convenio Europeo de Derechos Humanos, que establece claramente que todos tienen derecho a que su causa sea oída por un Tribunal independiente e imparcial.

En consecuencia, el art. 383 de la Ley de Enjuiciamiento Criminal, que autoriza a que el Juez de Instrucción aplique sin juicio previo las medidas de seguridad que el Código Penal prevé para los inimputables o incapaces de culpabilidad, debe ser entendido conforme a la Constitución. En este sentido el Juez de Instrucción sólo deberá adoptar una medida provisoria de seguridad, pero deberá remitir la causa a la Audiencia 
Precisamente, la línea mantenida en el voto particular de la STS de 2 de abril de 1993 es seguida posteriormente por la STS de 23 de julio de 2004 al validar el enjuiciamiento de una persona que carece de la necesaria capacidad procesal para ejercitar plenamente su derecho de defensa, por considerar más respetuoso con los derechos del inimputable la aplicación de la medida tras la celebración de un juicio ${ }^{31}$, en el que el tribunal pueda "apreciar, con intervención de letrado defensor, las pruebas existentes sobre la comisión de los hechos, autoría, etc. y el dictado de una Resolución que motive las conclusiones alcanzadas por el Juzgador, que omitir ese trámite esencial y pasar, directamente, a imponer una consecuencia tan aflictiva como el internamiento con pérdida de libertad, sin más constatación que la del que el sospechoso de haber cometido los hechos sufre una grave alteración psíquica" ${ }^{32}$.

Pese a la claridad del anterior pronunciamiento, el Alto Tribunal vuelve con rotundidad al criterio de la STS de 2 de abril de 1993, en la STS de 14 de junio de $2006^{33}$, cuando que considera que, si concurre enfermedad mental en el acusado al momento del inicio de las sesiones del juicio oral ${ }^{34}$, se

para que ésta juzgue de acuerdo a la ley al procesado que ha caído en estado de inimputabilidad".

31 Vid. también el AAP Barcelona 336/2018, de 29 de mayo (JUR 2018/235816).

32 STS 971/2004, 23 de julio (RJ 2004/7481). Para un estudio de esta sentencia, vid. HERNÁNDEZ GARCÍA, J., "Inculpado inimputable y derecho a conocer la acusación y a participar en el proceso: una decisión difícil, excesivamente deferente con un marco legal insostenible (sentencia de 23 de julio de 2004, ponente Sr. Maza Martín)", Revista del Poder Judicial, CGPJ, núm. 76, 2004, págs. 8-15.

33 STS 669/2006, de 14 de junio (RJ 2006/4759). Para un estudio de esta sentencia, vid. BACH FABREGÓ, R., "Un esperado, y necesario, giro jurisprudencial en el tratamiento del inculpado enfermo mental en el proceso", Revista del Poder Judicial, CGPJ, núm. 83, 2006, págs. 15-20.

34 En relación a la intensidad o grado de la enfermedad mental que determine la falta de capacidad del sujeto pasivo del proceso penal, la STS 
vulnera el derecho de defensa ante la quiebra de principio de contradicción, así como el derecho a la tutela judicial efectiva reconocido en el art. 24.1 $\mathrm{CE}$ con la exigencia de que en ningún momento pueda producirse indefensión, así como el derecho a la autodefensa como participación activa; ello toda vez que se le impide ejercitar de forma consciente la intervención que la LECrim le asigna en dicho acto y su derecho constitucional de defensa, tanto en la faceta de su propio interrogatorio afrontado con capacidad y conciencia del derecho a declarar o a guardar silencio, a su comunicación con el letrado a la vista de las vicisitudes del juicio y su derecho a la última palabra, derechos que no se pueden hacer valer sin la capacidad mental y volitiva imprescindible.

Concluye la citada sentencia que "Consecuentemente procede con estimación de los recursos interpuestos, acordar

10/2018, de 15 enero (RJ 2018/24), se refiere a una "merma cognitiva de entidad suficiente para incapacitarla para percatarse de las imputaciones que se le hacían y para enfrentarse a ellas" de modo que ratifica el criterio de entender procedente celebrar el juicio oral en caso de trastorno cognitivo leve-moderado si, como consecuencia de ese trastorno, la capacidad psíquica para asistir a las sesiones del juicio oral se encontraba alterada, pero no anulada, de suerte que no era imprescindible acordar el archivo de la causa sino que el deterioro moderado debía únicamente tenerse en cuenta al valorar sus manifestaciones. De este modo ante un supuesto de un déficit cognitivo moderado, el criterio de celebrar juicio oral no se opone a lo dispuesto en el art. 383 LECrim ni a la jurisprudencia que lo interpreta. La STS 749/2017, de 21 de noviembre (RJ 2017/5223), en el caso de un acusado que tenía afectado su estado mental debido a un padecimiento de Alzheimer con posterioridad a la conducta delictiva, ha señalado que el hecho de que el tribunal de instancia considerara pertinente celebrar el juicio oral contra él basándose en los dictámenes médicos en un caso de un trastorno cognitivo levemoderado, que se manifestaba clínicamente por alteraciones de atención, orientación, memoria, lenguaje y en la organización y planificación de tareas, y que como consecuencia de ese trastorno, la capacidad psíquica para asistir a las sesiones del juicio oral se encontraba alterada, pero no anulada, no era imprescindible acordar el archivo de la causa con respecto al mismo, sino que el deterioro moderado debía únicamente tenerse en cuenta al valorar sus manifestaciones, desestimándose por tanto el motivo del recurso. 
la nulidad del juicio oral y sentencia subsiguiente, y asimismo la suspensión provisional y archivo de la causa, bien entendido que el Tribunal deberá supervisar con la periodicidad necesaria el estado de salud del procesado y en caso de que pudiera restablecerse en condiciones de poder afrontar el juicio oral, esto es si desaparecen las causas que han motivado la anulación y suspensión del juicio oral, deberá ser éste celebrado por un Tribunal distinto del que ha conocido de la resolución recurrida.

Caso contrario si se acredita que la demencia o incapacidad mental del procesado es de carácter permanente e irreversible en sus efectos, sin posibilidad de episodios lúcidos, deberá cesar toda intervención penal sobre el mismo, dándose traslado de las actuaciones al Ministerio Fiscal para que éste inste en el orden jurisdiccional civil las medidas pertinentes en materia de incapacitación o internamiento del afectado -lo que en el caso presente ya se ha producido con la declaración judicial de incapacitación, internamiento administrativo y sumisión a tutela- para evitar un nuevo comportamiento criminal y remediar esa inexistente capacidad de autodeterminación”.

35 Esta interpretación es seguida, entre otras, por las resoluciones: AAP de Jaén 90/2019, de 13 de febrero (JUR 2019/145033); AAP de Valencia 724/2018 (JUR 2018/247876), de 12 de julio; AAP de Granada 494/2018, de 29 de junio (JUR 2018/262756); AAP de Murcia 360/2018, de 28 de mayo (JUR 2018/197080); AAP de Tarragona 850/2017, de 24 de noviembre (JUR 2018/46574); AAP de A Coruña 610/2017, 12 de julio (JUR 2017/215683); AAP de La Rioja 141/2017, de 2 de mayo (JUR 2017/188689). Por su parte el AAP de Lugo 347/2005, de 19 de diciembre (JUR 2006/42005) afirma que este principio general relativo a que cuando la demencia sobreviene después de cometido el delito, se concluye el sumario y se manda archivar la causa, lo establece de manera clara el art. 383 LECrim, y tal principio no solo es extrapolable al procedimiento de la Ley del Juzgado por la aplicación supletoria de la Ley, sino que el propio art. 32 LOTJ establece que acreditada la exención legalmente pertinente no es otro que el sobreseimiento libre del art. 637.3 LECrim, por lo que siendo rotundo del informe forense respecto a la situación de enajenación mental completa del acusado, procede sobreseer la causa. 
Ahondando en esta misma posición, la STS de 24 de noviembre de 2010 sostiene que se impone una interpretación del art. 383 de la LECrim que posibilite la armonización de los derechos fundamentales, de defensa y audiencia ${ }^{35}$, que se enmarcan en los derechos más elementales de un proceso justo, y se hace eco de la doctrina de la STS de 14 de junio de 2006, concluyendo de forma idéntica en relación a la interpretación del art. $383 \mathrm{LECrim}^{36}$, pero sin aludir a la misma explícitamente ${ }^{37}$.

36 La STS 550/2017, de 12 de julio (RJ 2017/3688), en una causa que el Tribunal se planteó de oficio las consecuencias de la enfermedad del acusado, decide no proseguir la tramitación respecto del mismo haciéndolo, sin embargo, contra los demás acusados, señalando que "Aunque en el referido auto se alude, como fundamento de la decisión, al artículo 383, que aplica por analogía, en realidad lo que está decidiendo es la suspensión del juicio oral respecto a uno de los acusados, prevista en el artículo $746.5^{\circ}$ de la LECrim. Es cierto que en ese precepto se contempla el supuesto de enfermedad repentina que impida al acusado estar presente en el juicio, pero también lo es que la situación es idéntica si el estado de salud de aquel, aunque no sea repentino, le impide asistir al juicio haciendo imposible que pueda ejercer en el mismo sus derechos. Pues de lo que se trata es, en el fondo, de asegurar que el acusado, cuando llega el momento del juicio oral que se celebra en su contra, esté en condiciones de ejercer adecuadamente su derecho de defensa. De manera que lo que la ley prevé es la suspensión del juicio oral cuando el acusado esté enfermo de forma que no pueda estar presente en el juicio. El artículo 383, por su parte, se refiere a los casos en los que el acusado, a causa de su estado mental, no está en condiciones de percatarse de la trascendencia del plenario y, por lo tanto, tampoco puede ejercer adecuadamente sus derechos.

La ley contiene para estos casos de suspensión del juicio para alguno de los acusados, algunas otras previsiones, que deben ser observadas. En primer lugar, en el artículo 749 se atiende a la posibilidad de que haya de prolongarse indefinidamente la suspensión del juicio, debiendo entonces declararse sin efecto la parte del juicio que ya se hubiera celebrado, en caso de que se hubiera iniciado. De este precepto resulta que la ley ha previsto que la enfermedad, causa de la suspensión, no desaparezca en un breve plazo de tiempo. En segundo lugar, el artículo 746, en el último párrafo, dispone que el juicio no se suspenderá por enfermedad o incomparecencia de alguno de los procesados citados personalmente, siempre que el Tribunal estimare, con audiencia de las partes y haciendo constar en el acta del juicio las razones de la decisión, que existen 
De otro lado, la STS de 23 de diciembre de 2014, en referencia a aquellos supuestos en que se acuerde el archivo del proceso en cuanto a la responsabilidad penal de uno de los acusados con motivo de su enfermedad mental y la continuación del proceso penal frente al resto de acusados, cuando en dicho proceso se sustancie la pretensión de nulidad de un negocio jurídico que afecte a la persona no acusada penalmente, viene a señalar que resultaría procesalmente posible decretar el archivo provisional en cuanto al enjuiciamiento penal del acusado pero mantener dentro del objeto procesal, de manera separada de su eventual responsabilidad penal que quedaría imprejuzgada, la petición de la nulidad de dicho negocio jurídico frente a ese sujeto pasivo. De este modo, con la presencia de todas las partes en el proceso, se podría resolver a medio del correspondiente pronunciamiento de la sentencia penal sobre la nulidad del negocio ${ }^{38}$.

elementos suficientes para juzgarles con independencia. Conforme al mismo, pues, el tribunal puede celebrar el juicio para los demás acusados, excluyendo al enfermo, pero debe hacer constar expresamente las razones que le asisten para creer que pueden juzgarse separadamente unos de otros".

37 La STS 1033/2010, 24 de noviembre (RJ 2010/9038), indica que "procede acordar la suspensión provisional y archivo de la causa, bien entendido que el Tribunal deberá supervisar con la periodicidad necesaria el estado de salud del procesado y en caso de que pudiera restablecerse en condiciones para afrontar el juicio oral, esto es si desaparecen las causas que han motivado la anulación y suspensión del juicio oral, deberá éste ser celebrado.... Caso contrario, si se acredita que la demencia o incapacidad mental del procesado es de carácter permanente e irreversible en sus efectos, sin posibilidad de episodios lúcidos, deberá cesar toda intervención penal sobre el mismo, dándose traslado de las actuaciones al Ministerio Fiscal para que inste en el orden jurisdiccional civil las medidas pertinentes en materia de incapacitación o internamiento del afectado... para evitar un nuevo comportamiento criminal y remediar esa inexistente capacidad de autodeterminación".

38 La STS 806/2014, de 23 de diciembre (RJ 2014/6890), afirma que "Su precaria salud mental imposibilitó su enjuiciamiento con garantías. Por eso, resolviéndose una cuestión previa al inicio del juicio, se acordó el archivo provisional respecto de ella en el mismo sentido que se había acordado respecto de otros dos acusados en condiciones análogas. El 
En apoyo de la posición jurisprudencial mantenida por el TS, la STC 191/2004 se pronuncia, obiter dicta, en los siguientes términos "En la demanda de amparo se reconoce que la prestación de tal declaración no resultaba posible, dada la incapacidad del imputado para prestarla, de manera que el argumento esgrimido únicamente podría conducir a la conclusión de carácter general, efectivamente alcanzada por la representación del demandante de amparo, de que en ningún caso cabe abrir juicio oral contra un inimputable, de-

art. 383 LECrim fundamentaba esa decisión, del todo correcta, adoptada con la aquiescencia de las acusaciones.

Pese a ello se decreta la nulidad de la donación, como contenido específico de la responsabilidad civil en los delitos de alzamientos de bienes conforme a una bien conocida jurisprudencia (arts. 1300 y ss. Código Civil). Tal pronunciamiento -y eso es también cuestión tan reiterada en la jurisprudencia que queda excusada la invocación de precedentes- exige que todas las partes intervinientes en el negocio que se anula y que, por tanto, ostentan un interés directo en su subsistencia sean traídos como partes al proceso penal. Si en ellas no concurren indicios de criminalidad su condición será asimilable a la de un tercero responsable civil. El estatus de un tercero responsable civil en un procedimiento penal no coincide con el del acusado. Existen sensibles variaciones explicables por su muy diferente condición (por todos y solo a título ejemplificativo, vid. arts. 850.2 ó 86 LECrim). Entre otras cosas el régimen de presencia física está señalada y justamente dulcificado. Ahora bien, siempre es imprescindible la presencia "material", es decir, mediante una dirección letrada que asuma la defensa de sus intereses y mantenga con ella una conexión comunicativa al menos potencial. (...) Hubiese sido procesalmente posible decretar el archivo provisional en cuanto al enjuiciamiento penal, pero mantener dentro del objeto procesal la petición frente a esta recurrente de la nulidad de la donación, separada de su eventual responsabilidad penal: es decir, como interesada en ese pronunciamiento que se anclaría solo en su calidad de donataria; y no como consecuencia de una participación penal cuyo enjuiciamiento se postergaba". Por su parte, la AAP de Tarragona 850/2017, de 24 de noviembre (JUR 2018/46574) sostiene que no resulta admisible la solución de fraccionar el procedimiento y llevar a cabo el enjuiciamiento de las pretensiones civiles de forma aislada, pues tal solución ignoraría que las responsabilidades civiles que en su caso pudieran establecerse dimanarían necesariamente de una previa resolución definitiva sobre la responsabilidad penal, aunque ésta fuera inexistente. 
biendo procederse, una vez comprobada su inimputabilidad penal, al sobreseimiento libre y archivo de las actuaciones (art. 637.3 LECrim)" ${ }^{\prime 39}$.

Asimismo, es preciso traer a colación la doctrina de la STC 77/2014 que, referida a la presencia física del acusado en juicio oral como exigencia del derecho a la tutela judicial efectiva (art. 24.1 CE), parte de considerar que el juicio oral es el momento decisivo en el que, con publicidad y plena contradicción, se hace efectivo el derecho de defensa. De este modo, dice el TC que respecto de las personas con discapacidad se debe despejar cualquier duda en relación con su participación en el proceso penal, por mandato del art. 9.2 $\mathrm{CE}$ que obliga a los poderes públicos a promover las condiciones para que la igualdad de los individuos sea efectiva, removiendo los obstáculos que impidan o dificulten su plenitud, con especial deber de protección y apoyo de que gozan las personas con discapacidad, recordando el mandato del art. $49 \mathrm{CE}$ a los poderes públicos para amparar a los disminuidos psíquicos para el disfrute de los derechos del Título I de la CE, entre los que se incardinan los derechos a la tutela judicial efectiva (art. 24.1 CE) y a un proceso con todas las garantías (art. 24.2 CE), debiendo asegurarse que las personas con discapacidad tengan acceso a la justicia en igualdad de condiciones con las demás en todos los procedimientos judiciales.

La citada STC 77/2014, si bien referida a un supuesto de incomparecencia injustificada del acusado, viene a concluir que ante la existencia de indicios de que dicho acusado pueda sufrir trastornos mentales que limiten su capacidad de comprensión y, por tanto, la relevancia de las consecuencias de su incomparecencia, se impone a los órganos judiciales el deber de desarrollar la actividad necesaria para despejar cualquier duda, impuesto por el art. 24.1 CE para evitar

39 STC 191/2004, de 2 de noviembre (RTC 2004/191). 
indefensión, lo que exigía verificar si esa discapacidad no era obstáculo para que el acusado comprendiera la relevancia de la citación y la advertencia de que podría ser juzgado en su ausencia. Esta argumentación, al versar sobre la discapacidad del sujeto respecto de su comprensión del significado de sus actos y las consecuencias del proceso penal, pudiera extrapolarse, siquiera en cierto modo, a la situación del enjuiciamiento penal ante la falta de capacidad procesal por enfermedad penal, al no poder comprender la significación de proceso ni tener aptitud mínima para intervenir en éste ${ }^{40}$.

Por su parte, el TEDH señala que, en conjunto, el art. $6 \mathrm{CEDH}$ garantiza el derecho de un acusado a participar de forma efectiva en un proceso penal. Por lo general, ello incluye no sólo el derecho a estar presente, sino también el derecho a ser, en caso necesario, asistido por un defensor y a seguir el proceso de forma eficaz. Dichos derechos están incluidos en la noción del principio de contradicción y pueden derivarse también de las garantías contenidas en los subapartados c) y e) del art. $6.3^{41}$.

Consecuentemente, para respetar las exigencias del derecho a estar presente en juicio, tanto desde la órbita del derecho de defensa como del derecho a un juicio justo, no puede bastar una mera presencia física del sujeto, sino que es preciso que en el plano mental o psíquico también esté presente, cuando menos con una mínima e indispensable capacidad que le permita seguir el proceso de forma eficaz.

40 STC 77/2014, de 22 mayo (RTC 2014/77).

41 En tales términos, se pronuncia la STEDH de 14 de enero de 2003, caso Lagerblom contra Suecia (TEDH 2003/4), e igualmente la STEDH de 25 de marzo de 1999, caso Pélissier y Sassi contra Francia (TEDH 1999/10). 


\section{La imposibilidad de celebración de juicio oral: afectación de garantías y derechos}

Para dar respuesta a la cuestión relativa a la posibilidad de enjuiciamiento penal de personas físicas sin la capacidad procesal mínima por padecer una enfermedad o trastorno mental, conscientes de las dificultades interpretativas que suscita, procede estar a la doctrina resultante de la evolución jurisprudencial reseñada, integrada como máximos exponentes por las citadas SSTS de 2 de abril de 1993 y, especialmente, de 14 de junio de 2006 y de 24 de noviembre de 2010; en todas ellas se considera incompatible con el derecho al proceso debido la celebración de juicio oral, aunque sea con la finalidad de imponer una medida de seguridad por causa de inimputabilidad, con la incapacidad del sujeto pasivo del proceso cuando dicho estado mental no le permita comparecer y actuar en el proceso con las mínimas garantías; sin duda, es ésta la interpretación más respetuosa y garantista con los derechos fundamentales ${ }^{42}$.

42 Comparten esta opinión, entre otros, FLORES PRADA, I., "Problemas del enjuiciamiento...", op. cit., pág. 10; FLORES PRADA, I., "Derechos fundamentales y garantías...", op. cit., pág. 16; GALDEANO SANTAMARÍA, A., "El maltratador de violencia de género inimputable versus esposa-cuidadora víctima de violencia de género", Diario La Ley, núm. 7967, Sección Doctrina, 2012, págs. 11 y 13; LLEDÓ GONZÁLEZ, C.L., "Enfermedad mental y jurisprudencia", Cuadernos Digitales de Formación, CGPJ, núm. 55, 2016, págs. 43; MORENO CATENA, V., "Enfermedad mental y capacidad en el proceso penal", en FLORES PRADA, I. (Dir.), SÁNCHEZ RUBIO, A. (Coord.), Trastornos mentales y justicia penal: Garantías del sujeto pasivo con trastorno mental en el proceso penal, Thomson Reuters Aranzadi, Cizur Menor (Navarra), 2017, págs. 78 y ss.; POZA CISNEROS, M., “¿Qué solución debe adoptarse...", op. cit., pág. 35; VARELA CASTEJÓN, X., "A persoa incapaz...”, op. cit., pág. 49. Por su parte, HERNÁNDEZ GALILEA ["El control de la capacidad procesal del investigado en el proceso penal", en FLORES PRADA, I. (Dir.); SÁNCHEZ RUBIO, A. (Coord.), Trastornos mentales y justicia penal: Garantías del sujeto pasivo con trastorno mental en el proceso penal, Thomson Reuters Aranzadi, Cizur Menor (Navarra), 2017, pág. 202] considera que "El enjuiciamiento debería ser excluido si el sujeto no está en condiciones de comprender el proceso 
Así, cuando se concluya de manera clara que el investigado o acusado carece de la capacidad para comprender el desarrollo del proceso, debe acordarse el archivo provisional del proceso, con eventual comprobación periódica de la evolución de aquél, la reapertura si se recobrase la capacidad necesaria o archivo definitivo, si la situación fuese irreversible; y, en todo caso, de ser necesario, con traslado al Ministerio Fiscal a efectos de adopción de las medidas civiles correspondientes ${ }^{43}$; como señala GÓMEZ COLOMER, "se comprende enseguida que es prácticamente imposible que imputado trastornado pueda comprender el alcance penal de los hechos que se le achacan, con lo que parece que no podrá defenderse del mismo adecuadamente" ${ }^{44}$.

Y es que la normativa aplicable exige, de acuerdo a las sentencias del Alto Tribunal, una obligada lectura constitucional, acomodada también a los instrumentos internacionales y disposiciones comunitarias sobre derechos fundamentales y proceso penal. En tal sentido, la Carta Magna en su art. 24 contiene el derecho constitucional a la tutela judicial efectiva, como derecho de acceso a los tribunales e intervenir en un proceso en condiciones de igualdad y sin indefensión (art. 24.1 CE), así como el derecho fundamental a un proceso justo o debido (art. 24.2 CE), sin obviar el mandato contenido

y su intervención en el mismo, pero, ya que se considera inevitable, si se solicitan medidas de seguridad, debería excluirse la eficacia de la conformidad sobre los hechos y exigir la adecuada justificación del riesgo de conducta violenta". LLEDÓ GONZÁLEZ ("Enfermedad mental y jurisprudencia”, Cuadernos Digitales de Formación, CGPJ, núm. 55, 2016, págs. 43) también admite algún mecanismo de complemento de la capacidad, a modo de un defensor judicial. QUINTERO OLIVARES (Locos y culpables, Aranzadi, Pamplona, 1999, págs. 130-131) afirma que "lejos de ser una marginación es el mejor favor que se le puede hacer".

43 POZA CISNEROS, M., “Qué solución debe adoptarse...”, op. cit., pág. 35.

44 GÓMEZ COLOMER, J.L., "Aspectos procesales”, en CARBONELL MATEU, J.C. (Coord.), Enfermedad mental y delito. Aspectos psiquiátricos, penales y procesales, Civitas, Madrid, 1987, pág. 156. 
en el art. $49 \mathrm{CE}$ a los poderes públicos para que amparen especialmente a los disminuidos físicos, sensoriales y psíquicos para el disfrute de los derechos que el Título I otorga, entre ellos los contenidos en el art. $24 \mathrm{CE}$.

La solución apuntada es también la más acorde al contenido de los precitados derechos previstos en los arts. 6 CEDH, 14 PIDCP, 11 DUDH o 48 CDFUE sobre derecho a un juicio justo, así como con la regulación de la Unión Europea sobre derechos y garantías básicas del sujeto pasivo en la justicia penal en lo que a derechos de investigados o procesados con trastorno mental se refiere, cristalizada en la Directiva 2016/343/UE, de 9 de marzo de 2016, por la que se refuerzan en el proceso penal determinados aspectos de la presunción de inocencia y del derecho a estar presente en el juicio, cuya finalidad consiste en reforzar en el proceso penal el derecho a un juicio justo, estableciendo unas normas mínimas comunes relativas a determinados aspectos de la presunción de inocencia y al derecho a estar presente en el juicio (Considerando 9). En concreto, en su art. 8 se recoge el derecho a estar presente en el juicio, para lo cual el Considerando 42 dispone que "Los Estados miembros deben garantizar que, en la aplicación de la presente Directiva, en especial con respecto al derecho a estar presente en el juicio y el derecho a un nuevo juicio, se toman en consideración las necesidades específicas de las personas vulnerables. Con arreglo a la Recomendación, de 27 de noviembre de 2013, de la Comisión Europea, relativa a las garantías procesales para las personas vulnerables sospechosas o acusadas en procesos penales, debe entenderse como acusados o sospechosos vulnerables, todos los acusados o sospechosos que no puedan comprender o participar eficazmente en un proceso penal debido a su edad, su condición mental o física, o a cualquier discapacidad que puedan tener".

No debe olvidarse además que el derecho fundamental al proceso justo o debido con todas las garantías (art. 
24.2 CE) exige el derecho a conocer la acusación y poder defenderse de ella, tanto a medio de la defensa técnica con asistencia de letrado que exige la posibilidad de comunicación eficaz con éste, como también la autodefensa, entendida como intervención activa y participación del sujeto pasivo del proceso en esa defensa ${ }^{45}$.

En relación a la problemática planteada, el respeto de los derechos y garantías fundamentales exigen que el sujeto pasivo esté investido de capacidad procesal, entendida como aptitud para intervenir consciente y eficazmente en la propia defensa como pieza clave del derecho a un proceso justo, y asimismo comprender el significado del proceso al que se ve sometido $^{46}$. De este modo, la consecuencia ha de ser la imposibilidad de continuar la tramitación del proceso penal por constar que el procesado se encuentra privado de capacidad para actuar de manera mínimamente válida o eficaz en el proceso, en suma, de esa ausencia de capacidad psíquica, traducida en incapacidad procesal, para comprender el alcance del eventual juicio y sus consecuencias, y ejercitar el derecho de defensa con mínimas garantías.

De otro lado, no ha de obviarse la necesidad de que exista un equilibrio inter partes en todo proceso penal, propio del principio de igualdad e interdicción de la indefensión, que resultaría quebrado cuando el sujeto sufre una dolencia o padecimiento mental. Asimismo, el principio o garantía de contradicción, que comprende el derecho a un juicio con todas las garantías (art. 24.2 CE) no se respeta si el encausado está aquejado por una enfermedad mental en tal grado de

45 GOMEZ DE LIAÑO DIEGO, R., "Exigencias del derecho de defensa...", op. cit., págs. 285-293.

46 GOMEZ DE LIAÑO DIEGO ("Exigencias del derecho de defensa...", op. cit., pág. 268) señala que "El problema es, en cualquier caso, que la apertura y la celebración del juicio entra también en absoluta contradicción con el derecho de defensa, sobre todo en su faceta de autodefensa, si este se celebra cuando la enfermedad mental del acusado es absoluta y de carácter permanente". 
intensidad que le impide discernir y comprender, por tanto, actuar, válidamente generando su palmaria indefensión.

\section{Reflexiones en torno a la situación actual y la necesidad de acudir a la vía civil}

Como se ha expuesto, el sujeto pasivo del proceso penal ha de gozar de la capacidad procesal mínima, y necesaria, para poder ser sometido el enjuiciamiento penal pues en caso de resultar acreditado que ello no es así, esa persona no puede intervenir válidamente como sujeto pasivo de un proceso penal.

La cuestión afecta al derecho a estar presente en juicio, tanto respecto del derecho de defensa como del derecho a un juicio justo, y para colmar sus exigencias no puede bastar una mera presencia física del sujeto sino que es preciso que en el plano mental o psíquico también esté presente, cuando menos con una mínima e indispensable capacidad que permita seguir el proceso de forma eficaz; y acometer una defensa adecuada parte de poder entender en qué consiste el juicio y la acusación para defenderse, comprender el proceso y sus consecuencias ${ }^{47}$, así como realizar las actuaciones inherentes a tales derechos en el seno del mismo: comprender los derechos que le asisten, admitir o no los hechos, guardar silencio, hacer uso de la última palabra ${ }^{48}$.

Y la conclusión alcanza a las personas inimputables en el momento de comisión de los hechos, a quienes se les habrá de imponer una medida de seguridad de las previstas

47 Es contundente MORENO CATENA ("Enfermedad mental...", op. cit., pág. 72) al señalar que dictar una sentencia condenatoria contra una persona que por su falta de capacidad no puede entender ni intervenir en el procedimiento convertiría a las actuaciones judiciales en una farsa intolerable.

48 GOMEZ DE LIAÑO DIEGO, R., "Exigencias del derecho de defensa...", op. cit., págs. 253-295. 
en el texto sustantivo penal, como consecuencia jurídica, pues su imposición sólo resultaría posible tras la celebración del juicio oral que ha de contar con las antedichas garantías y derechos; no se puede obviar que en dicho juicio se va a ventilar la autoría o participación en una acción típica y antijurídica y si el sujeto presenta la peligrosidad que justifica la medida postulada, no cabiendo la posibilidad de celebrar el juicio contradictorio, entendido como justo y con todas sus garantías, mientras el sujeto pasivo no tenga capacidad procesal por enfermedad o trastorno mental.

En este orden de consideraciones y avalando la posición sostenida, no se puede obviar que, en el ámbito del proceso de decomiso autónomo, introducido ex novo en la LECrim a medio de la Ley 41/2015 de 5 de octubre, de modificación de la Ley de Enjuiciamiento Criminal para la agilización de la justicia penal y el fortalecimiento de las garantías procesales, el art. 803 ter e 2 b) LECrim prevé como supuesto que habilita para tramitar el proceso de decomiso autónomo que el autor del hecho punible no pueda ser enjuiciado debido a su incapacidad para comparecer en juicio penal, precepto que hay que poner en relación con el art. 127 ter $\mathrm{CP}$ que, al regular la modalidad de decomiso autónomo, se refiere a la enfermedad crónica que impida el enjuiciamiento.

De este modo, la previsión legal parte, como premisa de base, de la existencia de una incapacidad para comparecer en juicio penal que impida el enjuiciamiento penal del sujeto pasivo, de suerte que la norma admite que dicha incapacidad venga a suponer la imposibilidad de someter a juicio penal al sujeto, incapacidad que puede ser temporal pero también irreversible en función de la naturaleza y gravedad del padecimiento o dolencia.

En cualquier caso, a nuestro entender, el concepto de incapacidad para comparecer en juicio previsto en el art 803 ter 2 b) LECrim, habrá de ser interpretado según la concepción referida a la capacidad procesal entendida como aptitud 
necesaria para participar conscientemente en el juicio y comprenderlo, así como para ejercer su derecho de defensa, lo que determina que, con fundamento en la naturaleza penal, sancionadora, de la institución del decomiso, así como en la naturaleza de proceso penal del proceso de decomiso autónomo, como cauce procesal para su imposición, debamos concluir la imposibilidad de someter al incapaz al proceso de decomiso autónomo, como enjuiciamiento penal en el cual se le atribuye la responsabilidad penal por unos hechos, aun cuando no tenga por objeto la condena por delito del sujeto ni la imposición de una pena stricto sensu, pues en caso contrario se vulnerarían los derechos y garantías que, como sujeto pasivo de una sanción penal en un proceso penal le amparan, esencialmente su derecho fundamental de defensa ${ }^{49}$.

En consecuencia, partiendo de la imposibilidad de someter a juicio penal a la persona física cuando ésta, por causa de enfermedad o trastorno mental se ve privada de la capacidad procesal mínima imprescindible a tal efecto, cumple plantearse la solución que en la práctica judicial haya de darse a la situación.

En tal sentido, respecto del proceso penal en tramitación la respuesta procedente a la cuestión, en términos de la citada STS de 14 de junio de 2006, sería la suspensión provisional y archivo de la causa, con supervisión periódica del estado de salud del procesado y, en caso de que pudiera restablecerse en condiciones de poder afrontar el juicio oral la celebración de plenario. En cambio, si se acredita que la incapacidad mental del procesado es de carácter permanente e irreversible en sus efectos, sin posibilidad de episodios lúcidos, deberá cesar toda intervención penal sobre el mismo, procediendo el archivo definitivo, dando traslado al MF para que inste en el orden jurisdiccional civil las medidas pertinentes en materia de incapacitación o internamiento del

49 Sobre esta cuestión, vid. FARTO PIAY, T., El proceso de decomiso autónomo, Tirant lo Blanch, Valencia, -en prensa-. 
afectado, para evitar un nuevo comportamiento criminal y remediar esa inexistente capacidad de autodeterminación ${ }^{50}$.

Consecuentemente, no podemos compartir la existencia de esa necesidad ineludible de aplicación de una medida de seguridad, que precisaría de la celebración de juicio oral, basada en un doble interés, tanto el terapéutico del enfermo como el de protección de los miembros de la sociedad ante un sujeto con potencial de peligrosidad.

$\mathrm{Y}$ es que, como ya se expuso, la imposición de una medida de seguridad implica la celebración de juicio oral a tal efecto, con la consiguiente declaración de autoría de los hechos y posterior determinación de las medidas que correspondan, lo que a nuestro criterio no resulta compatible con la ausencia de capacidad procesal del sujeto pasivo, la cual se erige en premisa de base para la celebración del juicio oral, aun cuando lo sea al exclusivo efecto de imponer la medida de seguridad, por lo que supone de vulneración de los derechos fundamentales que le asisten.

Tampoco el interés terapéutico del sujeto hace imprescindible la imposición de una medida de seguridad pues precisamente las medidas civiles previstas en nuestro ordenamiento jurídico van encaminadas a tutelar, y proteger, a la persona, acordando, tras la previa tramitación del procedimiento

50 No obstante, la Memoria de la FGE para el año 2018 establece una diferenciación. Así, tras considerar que el art. 383 LECrim es completamente inaplicable en lo relativo a la imposición de medidas de seguridad y la posibilidad de enjuiciar a aquellas personas a las que la enfermedad sobrevenida anule por completo su capacidad procesal. Para estos casos señala como procedente es el archivo provisional del procedimiento y la intervención desde el orden jurisdiccional civil. Dicho lo anterior hace una diferenciación respecto de los supuestos de inimputabilidad inicial y persistencia de incapacidad procesal, entendiendo que existe un vacío regulatorio, considerando que hay que dar tratamiento legal y respuesta bien a la posibilidad de su enjuiciamiento en el orden penal o bien, como en el supuesto anterior, desde la jurisdicción civil. Por ello propone que la LECrim adopte la solución conferida en el Proyecto de Código Penal de 2013 en los arts. 49 y 50. 
civil, la decisión que proceda; entre ellas, el internamiento con sometimiento a los tratamientos médicos y terapéuticos que sean acordes a la situación mental del sujeto, ya sea una medida cautelar, ex art. 762 LEC, o el internamiento involuntario por trastorno psíquico previsto en el art. $763 \mathrm{LEC}^{51}$.

En lo relativo a la necesidad de activar la protección social frente o derivada de la peligrosidad del sujeto, se entiende que ésta queda colmada con la adopción de esas medidas civiles, en la amplitud que sea necesaria y legalmente posible, medidas cuya naturaleza y eficacia a efectos de prevención no difieren de las medidas de seguridad a imponer en la jurisdicción penal. A ello debe añadirse que esa protección social no puede ser impuesta en un proceso penal obviando los derechos fundamentales del sujeto, cuando la reacción que ofrece el orden civil es suficiente y no conculca ni las garantías procesales ni los derechos constitucionalmente reconocidos.

En consecuencia, ante la situación de incapacidad del sujeto pasivo del proceso penal, que le imposibilita para ser sometido a enjuiciamiento penal, la solución debiera pasar por acudir a la jurisdicción civil para que se acuerden las medidas procedentes que habilita la legislación, entre ellas el internamiento involuntario del art. 763 LEC, preservando los derechos fundamentales de sujeto y las propias garantías del proceso penal, así como la prevención de actuaciones que pudieran volver a afectar a otras personas o bienes en particular, por tanto al interés social en general.

51 Sobre las distintas decisiones a adoptar desde una perspectiva política legislativa, vid. SANZ MORÁN, Á.J., "El inimputable ante el proceso penal", en DE HOYOS SANCHO, M. (Coord.), La víctima del delito y las últimas reformas procesales penales, Thomson Reuters Aranzadi, Cizur Menor (Navarra), 2017, págs. 312-314. Por su parte, VARELA CASTEJÓN ("A persoa incapaz...", op. cit., pág. 41) se refiere a la existencia de medidas de carácter civil para la tutela de esa persona e, incluso, para acordar su internamiento, con mención expresa del proceso regulado en el art. 763 LEC. 
Al respecto, procede hacer mención al régimen procesal que en relación a esta cuestión se otorga en la jurisdicción penal especial de menores por la LORPM. En tal sentido, debe partirse de que el art. 29 LORPM, bajo la rúbrica "Medidas cautelares en los casos de exención de la responsabilidad" establece que "Si en el transcurso de la instrucción que realice el Ministerio Fiscal quedara suficientemente acreditado que el menor se encuentra en situación de enajenación mental o en cualquier otra de las circunstancias previstas en los apartados $1^{\circ}, 2^{\circ}$ o $3^{\circ}$ del art. $20 \mathrm{CP}$, se adoptarán las medidas cautelares precisas para la protección y custodia del menor conforme a los preceptos civiles aplicables, instando en su caso las actuaciones para la incapacitación del menor y la constitución de los organismos tutelares conforme a Derecho, sin perjuicio todo ello de concluir la instrucción y de efectuar las alegaciones previstas en esta Ley conforme a lo que establecen sus arts. 5.2 y 9, y de solicitar, por los trámites de la misma, en su caso, alguna medida terapéutica adecuada al interés del menor de entre las previstas en esta Ley", precepto que pese a su título, en puridad y como se colige de su contenido, no regula auténticas medidas cautelares. El análisis del art. 29 LORPM debe partir de la premisa de que su aplicación está limitada a los supuestos de menores exentos de responsabilidad criminal, y en concreto se incluyen situaciones de enajenación mental o cualquiera otra de las circunstancias previstas en los apartados $1^{\circ}, 2^{\circ} \mathrm{o}$ $3^{\circ}$ del art. 20 CP. En tales supuestos, si durante la instrucción cuya competencia se residencia en el MF, queda suficientemente acreditada la exención de responsabilidad se prevén diversas actuaciones ${ }^{52}$.

Así, se dispone la adopción de medidas cautelares precisas para la protección y custodia del menor conforme a los

52 Obsérvese que el art. 29 LORPM es claro a la hora de indicar que la exención de responsabilidad debe quedar suficientemente acreditada durante la instrucción, no siendo suficiente con meras sospechas o indicios al respecto. 
preceptos civiles, de suerte que deberá acudirse a la legislación civil, y en concreto al art. 763 LEC que regula el internamiento por razón de trastorno psíquico, en este caso del menor, en un centro sanitario especializado, en el que seguir una terapia adecuada; o la adopción de las medidas de protección que se prevén en los arts. 172 y ss. CC y en la LO 1/1996, así como la normativa autonómica reguladora de esta materia. Para determinar la medida más adecuada para el menor, se tendrá en cuenta el principio de proporcionalidad, de forma que sólo se acordará el internamiento en los casos en que sea necesario al fin perseguido. Como señalamos, no se tratan de medidas cautelares que tiendan a garantizar el desarrollo del proceso frente al menor, sino más bien, de medidas de naturaleza protectora o de cuidado del mismo ${ }^{53}$.

Asimismo, se refiere también el art. 29 LORPM a "las actuaciones para la incapacitación del menor y la constitución de los organismos tutelares de menores". Nuevamente nos encontramos ante medidas que no gozan de naturaleza cautelar, sino que son medidas de protección civiles. Establece el precepto la obligación del fiscal de instar la declaración de incapacidad del menor y la adopción de las correspondientes medidas de protección en relación al mismo, en aquellos casos en que se derive que ese menor está incurso en una causa de incapacitación de acuerdo con el art. 200 CC. Estas medidas deberán ser adoptadas en un proceso de incapacitación cuya tramitación corresponde al Juez de Primera Instancia o de Familia del lugar de residencia del menor (art. 756 LEC).

No obstante, el art. 29 LORPM establece que, además de instar las medidas de protección referidas, el fiscal debe "al concluir la instrucción, efectuar las alegaciones previstas conforme a lo establecido en los artículos 5.2 y 9 LORPM y

53 GONZÁLEZ PILLADO, E., "Medidas cautelares", en GONZÁLEZ PILLADO, E. (Coord.), Proceso penal de menores, Tirant lo Blanch, Valencia, 2008, págs. 196-197. 
solicitar, por los trámites del proceso previsto en la misma, alguna medida terapéutica adecuada al interés del menor de entre las previstas en esta ley". Se trata, en estos casos, de que el fiscal solicite en su escrito de alegaciones la adopción de alguna de las medidas terapéuticas previstas en la Ley ${ }^{54}$, a efectos de que el Juez de Menores pueda acordar en sentencia aquélla medida definitiva que estime más adecuada, a la vista del interés del menor. Esta previsión legislativa, de imposición de una medida a un menor en sentencia, cuando ha quedado acreditada la exención de responsabilidad criminal por alguna de las circunstancias del art. $20.1^{\circ}$ o $3^{\circ} \mathrm{CP}$, vendría a integrar una solución similar a la prevista en el art. 782.1 LECrim.

Ahora bien, pese a la expresa dicción del art. 29 LORPM, en cuanto al Expediente de menores, su tramitación y finalización, debe reseñarse que el art. 30.4 LORPM establece que el MF podrá también solicitar del juez de menores el sobreseimiento de las actuaciones por alguno de los motivos previstos en la LECrim, así como la remisión de los particulares necesarios a la entidad pública de protección de menores en su caso. Entre esas posibles previsiones de la LECrim se encuentra lo dispuesto en los arts. 381 y 383, en caso de que el menor carezca de la capacidad suficiente debido a una enfermedad mental, bien desde un inicio bien de manera sobrevenida, de modo que, en principio parece admisible que el MF pueda solicitar el sobreseimiento por tales causas.

En tal supuesto, en que se no se solicita la apertura de la fase de audiencia, el art. 33 LORPM, titulado "otras decisiones del Juez de Menores", dispone que, a la vista de la petición del MF y de las alegaciones de las partes, el juez adoptará, entre otras y en lo que nos atañe, la decisión prevista en su apartado c), referida al archivo por sobreseimiento de las actuaciones con remisión de particulares a la

54 En concreto, el internamiento terapéutico o el tratamiento ambulatorio [art. 7.1 d) y e) LEC]. 
entidad pública de protección de menores correspondiente cuando así se haya solicitado por el $\mathrm{MF}$, lo que se antoja una solución al proceso penal más adecuada y conforme a los derechos y principios expuestos si consideramos que el menor, por su falta de capacidad, no puede ser sometido a enjuiciamiento penal para la imposición de una medida, ni aun de carácter terapéutico, sin perjuicio, evidentemente, de aquellas medidas que se hubiesen o hayan de adoptar en el orden jurisdiccional civil.

\section{Conclusiones}

Resulta palmario que la enorme relevancia, en particular por la afectación de derechos fundamentales, que suscita la posibilidad de someter a enjuiciamiento penal a personas que, a consecuencia de la enfermedad o trastorno mental que padecen, carecen de la capacidad procesal, mínima y necesaria, que les impide conocer y participar válidamente en el proceso, exige dotar a la cuestión de un tratamiento legal uniforme, con una regulación procesal clara, coherente y sistematizada que ponga fin a la actual regulación procesal que, por deficitaria, no otorga una adecuada protección a los derechos fundamentales del sujeto pasivo del proceso.

En esa situación de indefinición regulatoria ahonda más, si cabe, la existencia de criterios dispares en la doctrina jurisprudencial del TS sobre la solución a otorgar a dicha cuestión, con la evidente quiebra de la seguridad jurídica tanto para nuestros órganos jurisdiccionales y operadores jurídicos como para el justiciable. De este modo, deviene imprescindible dotar al enjuiciamiento penal de personas privadas de capacidad procesal por enfermedad mental de una regulación unívoca que clarifique cuál ha de ser la respuesta que los tribunales deben otorgar a la situación.

En tal sentido, de lege ferenda, esa normativa debería abogar por el modelo propuesto que determine la 
imposibilidad de someter a juicio penal al sujeto pasivo con incapacidad procesal y remitir la cuestión a la jurisdicción civil en orden a la adopción de las medidas civiles oportunas previstas en el ordenamiento civil. Y ello por entender que dicha solución es la que se muestra respetuosa con los principios del proceso penal y los derechos fundamentales plasmados en nuestra $\mathrm{CE}$, en los instrumentos internacionales y la normativa comunitaria de aplicación; especialmente en lo que se refiere al respeto a la tutela judicial efectiva, como derecho de acceso a los tribunales e intervenir en un proceso en condiciones de igualdad y sin indefensión, y al derecho fundamental a un proceso justo o debido con todas las garantías, cuyo fundamento exige el respeto al derecho a conocer la acusación y poder defenderse, tanto a medio de la defensa técnica como en su vertiente de autodefensa, concebida como una participación activa del sujeto pasivo del proceso; todo ello, sin obviar el necesario equilibrio entre las partes del proceso, inherente al principio de igualdad.

\section{Bibliografía}

ARNÁIZ SERRANO, A., "Adecuación de las vigentes medidas cautelares a aplicar sobre investigados con trastorno mental", en FLORES PRADA, I. (Dir.), SÁNCHEZ RUBIO, A. (Coord.), Trastornos mentales y justicia penal: Garantías del sujeto pasivo con trastorno mental en el proceso penal, Ed. Thomson Reuters Aranzadi, Cizur Menor (Navarra), 2017, págs. 235-252.

BACH FABREGÓ, R., "Un esperado, y necesario, giro jurisprudencial en el tratamiento del inculpado enfermo mental en el proceso", Revista del Poder Judicial, CGPJ, núm. 83, 2006, págs. 15-20.

DE LA ROSA CORTINA, J.M., "Capacidad y proceso penal", Revista Aranzadi de Derecho y Proceso Penal, núm. 43, 2016, págs. 23-77. 
DE LA ROSA CORTINA, J.M., "Medidas cautelares personales en supuestos de graves anomalías psíquicas", $L a$ Ley Penal, núm. 108, 2014, págs. 1-29.

FARTO PIAY, T., El proceso de decomiso autónomo, Tirant lo Blanch, Valencia, -en prensa-.

FARTO PIAY, T., "¿Ha de someterse a juicio a quien carece de capacidad procesal por padecer problemas de salud mental?", Revista de la Facultad de Ciencias Jurídicas y del Trabajo de la Universidad de Vigo, núm. 4, 2018, págs. 1-5.

FLORES PRADA, I., Peligrosidad social predelictual y trastorno mental, Thomson Reuters Aranzadi, Cizur Menor (Navarra), 2017.

FLORES PRADA, I., "Garantías constitucionales en el enjuiciamiento de acusados con falta de capacidad procesal por trastornos mental grave", en FLORES PRADA, I. (Dir.), SÁNCHEZ RUBIO, A. (Coord.), Trastornos mentales y justicia penal: Garantías del sujeto pasivo con trastorno mental en el proceso penal, Thomson Reuters Aranzadi, Cizur Menor (Navarra), 2017, págs. 363-445.

FLORES PRADA, I., "Derechos fundamentales y garantías del investigado con trastorno mental en el moderno sistema de justicia penal", en FLORES PRADA, I. (Dir.), Derechos y garantías del investigado con trastorno mental en el sistema de justicia penal, págs. 14-22 (http://www.trastornosmentalesyjusticiapenal.com/ wp-content/uploads/Informe $\% 20$ inicial $\% 20 \mathrm{I} \% 2 \mathrm{bD}$. pdf, última consulta: 17/10/2019).

FLORES PRADA, I., "Problemas del enjuiciamiento de delitos violentos cometidos por inimputables", Revista Aranzadi de Derecho y Proceso penal, núm. 22, 2009, págs. 1-27.

GALDEANO SANTAMARÍA, A., "El maltratador de violencia de género inimputable versus esposa-cuidadora víctima de violencia de género", Diario La Ley, núm. 7967, Sección Doctrina, 2012, págs. 1-15. 
GARCÍA SAN MARTÍN, J., "Incapacidad de obrar "versus inimputabilidad: dos realidades no necesariamente convergentes", en FLORES PRADA, I. (Dir.), SÁNCHEZ RUBIO, A. (Coord.), Trastornos mentales y justicia penal: Garantías del sujeto pasivo con trastorno mental en el proceso penal, Ed. Thomson Reuters Aranzadi, Cizur Menor (Navarra), 2017, págs. 173-183.

GIMENO SENDRA, V., Manual de Derecho Procesal Penal, $2^{\mathrm{a}}$ edición, Ediciones Jurídicas Castillo de Luna, Madrid, 2018.

GÓMEZ DE LIAÑO DIEGO, R., "Exigencias del derecho de defensa de los enfermos mentales investigados/acusados en un proceso penal", en FLORES PRADA, I. (Dir.), SÁNCHEZ RUBIO, A. (Coord.), Trastornos mentales y justicia penal: Garantías del sujeto pasivo con trastorno mental en el proceso penal, Ed. Thomson Reuters Aranzadi, Cizur Menor (Navarra), 2017, págs. 253-295.

GÓMEZ DE LIAÑO DIEGO, R., "Exigencias del derecho de defensa de los enfermos mentales investigados en un proceso penal", en FLORES PRADA, I. (Dir.), Derechos y garantías del investigado con trastorno mental en el sistema de justicia penal, págs. 71-85. Disponible en el siguiente enlace: http://www.trastornosmentalesyjusticiapenal.com/wp-content/uploads/Informe $\% 20$ inicial $\% 20 I \% 2 b D$.pdf (última consulta: 17/10/2018).

GÓMEZ COLOMER, J.L., "Aspectos procesales", en CARBONELL MATEU, J.C. (Coord.), Enfermedad mental $y$ delito. Aspectos psiquiátricos, penales y procesales, Civitas, Madrid, 1987, págs. 75-168.

GONZÁLEZ PILLADO, E., "Medidas cautelares", en GONZÁLEZ PILLADO, E. (Coord.), Proceso penal de menores, Tirant lo Blanch, Valencia, 2008, págs. 159-202.

GRIMA LIZANDRA, V., "El derecho de defensa del imputado con graves anomalías psíquicas", Revista Jurídica de la Comunidad Valencia: jurisprudencia 
seleccionada de la Comunidad Valenciana, núm. 34, 2010, págs. 67-84.

HERNÁNDEZ GALILEA, J.M., "El control de la capacidad procesal del investigado en el proceso penal", en FLORES PRADA, I. (Dir.), SÁNCHEZ RUBIO, A. (Coord.), Trastornos mentales y justicia penal: Garantías del sujeto pasivo con trastorno mental en el proceso penal, Ed. Thomson Reuters Aranzadi, Cizur Menor (Navarra), 2017, págs. 185-207.

HERNÁNDEZ GARCÍA, J., "Inculpado inimputable y derecho a conocer la acusación y a participar en el proceso: una decisión difícil, excesivamente deferente con un marco legal insostenible (sentencia de 23 de julio de 2004, ponente Sr. Maza Martín)", Revista del Poder Judicial, CGPJ, núm. 76, 2004, págs. 8-15.

LLEDÓ GONZÁLEZ, C.L., "Enfermedad mental y jurisprudencia", Cuadernos Digitales de Formación, CGPJ, núm. 55, 2016, págs. 1-47 (http://poderjudicial.es, última consulta: 27/07/2019).

MORENO CATENA, V., "Enfermedad mental y capacidad en el proceso penal", en FLORES PRADA, I. (Dir.) y SÁNCHEZ RUBIO, A. (Coord.), Trastornos mentales y justicia penal: Garantías del sujeto pasivo con trastorno mental en el proceso penal, Ed. Thomson Reuters Aranzadi, Cizur Menor (Navarra), 2017, págs. 69-88.

MORENO CATENA, V., CORTÉS DOMÍNGUEZ, V., Derecho Procesal penal, $9^{\text {a }}$ edición, Tirant lo Blanch, Valencia, 2019.

MUÑIZ ANTEQUERA, A.J., "Derecho de defensa, juicio oral y acusado con incapacidad procesal por trastorno mental. Alternativas al enjuiciamiento mental de incapaces", en FLORES PRADA, I. (Dir.), SÁNCHEZ RUBIO, A. (Coord.), Trastornos mentales y justicia penal: Garantías del sujeto pasivo con trastorno mental en el proceso penal, Ed. Thomson Reuters Aranzadi, Cizur Menor (Navarra), 2017, págs. 343-361. 
ORTEGA LORENTE, J.M., “44. ¿El acusado psíquicamente discapacitado, puede intervenir en juicio con la mera asistencia de letrado, o debe estar asistido, también, por su tutor, guardador de hecho o defensor judicial?", en BACH FABREGÓ, R., (Dir.), 84 cuestiones sobre la dirección y publicidad del juicio oral, CGPJ, Madrid, 2011, págs. 164-168.

POZA CISNEROS, M., “¿Qué solución debe adoptarse en el caso de que se advierte que el imputado carece de la capacidad para comprender el desarrollo del proceso, en especial cuando ello se debe a una limitación que ya existía en el momento de comisión del delito?", en HERNÁNDEZ GARCÍA, J. (Dir.), Manuales de formación continuada (ejemplar dedicado a 99 cuestiones básicas sobre la prueba en el proceso penal), CGPJ, Madrid, núm. 51, 2009, págs. 31-43.

QUINTERO OLIVARES, G., "Culpabilidad, imputabilidad y capacidad procesal en el derecho en el derecho penal y en el enjuiciamiento de personas con trastorno mental”, en FLORES PRADA, I. (Dir.), SÁNCHEZ RUBIO, A. (Coord.), Trastornos mentales y justicia penal: Garantías del sujeto pasivo con trastorno mental en el proceso penal, Thomson Reuters Aranzadi, Cizur Menor (Navarra), 2017, págs. 33-68.

QUINTERO OLIVARES, G., Locos y culpables, Aranzadi, Pamplona, 1999.

SÁNCHEZ RUBIO, A., "Las garantías de defensa en el enjuiciamiento del enfermo mental", en ÁLVAREZ ALARCÓN, A., GARCÍA MOLINA, P. (Dirs.), CONDE FUENTES, J., ARRABAL PLATERO, P. (Coords.), Tendencias actuales del Derecho Procesal, Comares, 2019, págs. págs. 91-105.

SÁNCHEZ RUBIO, A., "La celebración de juicio oral contra enfermos mentales con incapacidad procesal plena", en FLORES PRADA, I. (Dir.), Derechos y garantías del investigado con trastorno mental en el sistema 
de justicia penal, págs. 107-115 (http://www.trastornosmentalesyjusticiapenal.com/wp-content/uploads/ Informe $\% 20$ inicial $\% 20 I \% 2 b D$.pdf, última consulta: 17/10/2018).

SANZ MORÁN, Á.J., "El inimputable ante el proceso penal", en DE HOYOS SANCHO, Montserrat (Coord.), La víctima del delito y las últimas reformas procesales penales, Thomson Reuters Aranzadi, Cizur Menor (Navarra), 2017, págs. 295-314.

SANZ MORÁN, Á.J., "La situación procesal del inimputable", en ARANGÜENA FANECO, C. (Coord.), Garantías procesales en los procesos penales en la Unión Europea, Lex Nova, Valladolid, 2007, págs. 327-344.

VARELA CASTEJÓN, X., "A persoa incapaz ante o proceso penal”, Revista Xurídica Galega, núm. 69, 2010, págs. 29-49. 